\title{
CORRECTION
}

\section{Correction to: Reducing the arbitrary: fuzzy detection of microbial ecotones and ecosystems - focus on the pelagic environment}

Antoine Bagnaro ${ }^{1 *}$, Federico Baltar ${ }^{1,2,3}$, Gretchen Brownstein ${ }^{4}$, William G. Lee ${ }^{4}$, Sergio E. Morales ${ }^{5}$, Daniel W. Pritchard ${ }^{1,6}$ and Christopher D. Hepburn ${ }^{1}$

\section{Correction to: Environ Microbiome 15, 16 (2020) https://doi.org/10.1186/s40793-020-00363-w}

Following publication of the original article [1], the authors reported an error with the positioning of the figures; the positions of Figs. 4 and 5 (not including the captions) had been erroneously swapped.

The original article [1] has been updated to correct this error.

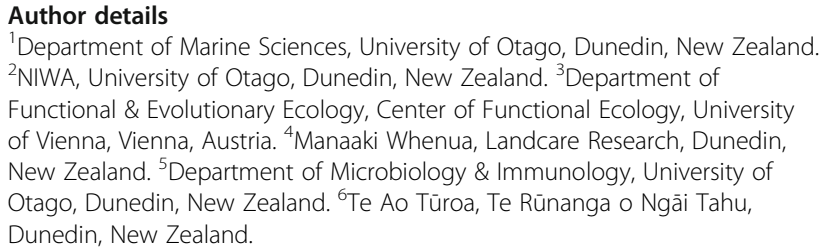

Published online: 30 November 2020

\section{Reference}

1. Bagnaro A, Baltar F, Brownstein G, et al. Reducing the arbitrary: fuzzy detection of microbial ecotones and ecosystems - focus on the pelagic environment. Environ Microbiome. 2020;15:16. https://doi.org/10.1186/ s40793-020-00363-w.

The original article can be found online at https://doi.org/10.1186/s40793 020-00363-w.

* Correspondence: antoine.bagnaro@postgrad.otago.ac.nz

${ }^{1}$ Department of Marine Sciences, University of Otago, Dunedin, New Zealand Full list of author information is available at the end of the article

C C The Author(s). 2020 Open Access This article is licensed under a Creative Commons Attribution 4.0 International License, which permits use, sharing, adaptation, distribution and reproduction in any medium or format, as long as you give appropriate credit to the original author(s) and the source, provide a link to the Creative Commons licence, and indicate if changes were made. The images or other third party material in this article are included in the article's Creative Commons licence, unless indicated otherwise in a credit line to the material. If material is not included in the article's Creative Commons licence and your intended use is not permitted by statutory regulation or exceeds the permitted use, you will need to obtain permission directly from the copyright holder. To view a copy of this licence, visit http://creativecommons.org/licenses/by/4.0/ The Creative Commons Public Domain Dedication waiver (http://creativecommons.org/publicdomain/zero/1.0/) applies to the data made available in this article, unless otherwise stated in a credit line to the data. 